\title{
DIFFERENCES OF MOTOR PROFICIENCY IN PRESCHOOL GIRLS RELATED TO ORGANIZED PHYSICAL ACTIVITY
}

\author{
Ivana Djordjević ${ }^{\mathrm{ABCDE}}$, Hana Valkova ${ }^{2 \mathrm{ABDE}}$, Emilija Petkovic $^{3 \mathrm{ABCD}}$ \\ ${ }^{1}$ Palacky University Olomouc \\ ${ }^{2}$ Masaryk University \\ ${ }^{3}$ University of Niš \\ Authors' Contribution: A - Study design; B - Data collection; C - Statistical analysis; D - Manuscript Preparation; E - Funds Collection
}

Corresponding Author: Ivana Djordjević, E-mail: hacienda018@hotmail.com

Accepted for Publication: November 24, 2021

Published: December 25, 2021

DOI: $10.17309 /$ tmfv.2021.4.11

\begin{abstract}
This study purpose was to determine the level of motor competence and differences in motor skills of preschool girls aged 5 to 7 from Serbia according to participation in organized physical activities.

Materials and methods. Ninety-one girls aged 5-7 years (mean \pm 6.4 ) were divided into three subsamples: control group, rhythmic gymnastics and sports school. Girls were assessed with the MABC-2 test. Descriptive statistics analyzed the basic characteristics of participants according to the level of motor competence. Furthermore, Pearson's $\chi 2$ test for contingency tables, MANOVA and discriminant analysis were employed to find differences in motor proficiency among groups.

Results. Significant differences have been found in girls attending rhythmic gymnastics in aiming \& catching on the upper bound of moderate effect size $\left(p<0.001, \eta^{2}=139\right)$, and total test score moderate effect size $(p=0.006$, $\left.\eta^{2}=0.105\right)$ compared to girls who did not participate in organized physical activity. The discrimination coefficient explained the differences in girls in aiming and catching, with a contribution of $41.4 \%$, balance skills with $24 \%$, and a total test score of $22.9 \%$. According to the level of motor competence, $61 \%$ from the control group and $40 \%$ from the sports school group scored below average in aiming \& catching. The total test score of $\geq 50$ percentile was achieved by $68.3 \%$ of girls in the control group, $84 \%$ in the sports school group, and $96 \%$ in rhythmic gymnastics.

Conclusion. This study confirms that sports practice contributes to the development of motor capabilities and influences individual differences in children's scores. Our findings can contribute to understanding how important it is to promote object control skills games for girls and older preschoolers generally.

Keywords: motor competence, preschool, girls, organized physical activity, MABC-2.
\end{abstract}

\section{Introduction}

The characteristics of preschool children in terms of integrity mean that the motor, physical, cognitive and conative aspects of child development are closely related. Development in one domain of physical abilities affects development in another domain. Motor development is understood as changes in motor behaviour along the life span and increased capacity to perform specific skills (Sugden \& Wade, 2013). Such changes are continuous and provided by the interaction among constraints over the body, the environment and the task (Newell, 1986). Motor skills development during the growth process is influenced by various internal and external factors such as gender, age, and physical activity (Giagazoglou et al., 2011; Venetsanou \& Kambas, 2010). Motor pro-

(C) Djordjević, I., Valkova, H., \& Petkovic, E., 2021. ficiency develops during preschools through various forms of physical activity such as running, jumping, catching, and throwing. According to the authors, Gallahue and Ozmun (2006) and MacNamara et al. (2011), these motoric skills used in everyday recreational activities can be the basis for creating more complex movements. In addition, executing different motor acts, including balance coordination, constitutes motor skills (Henderson, Sugden, \& Barnett, 2007). Typically developing children will acquire an entire range of fundamental movement skills that naturally occurs throughout development till the end of preschool (Hardy, King, Farrell, Macniven, \& Howlett, 2010).

Motor competence can be viewed as a determinant of participation and levels of physical activity (Stodden et al., 2008; Wrotniak, Epstein, Dorn, Jones, \& Kondilis, 2006). Consequently, poor motor performance may cause ad- 
verse influence in preschool children on everyday life tasks, educational settings, and participation in sport-related PA (Henderson, Sugden, \& Barnett, 2007). Longitudinal studies have shown that children with low motor competence tend to be less physically active than children with higher motor competence, and that trend continues through adolescence and adulthood (Barnett et al., 2008; Hands, 2008). Furthermore, motor competence has been related to physical fitness (Ivashchenko, Nosko, Bartik, \& Makanin, 2020; Haga, 2008a; Hands, 2008) and self-perception (Barnett, Morgan, van Beurden, \& Beard, 2008; Vedul-Kjelsås, Sigmundsson, Stensdotter, \& Haga, 2012). On the contrary, reduced physical activity in children with low motor competence may be associated with lower performance levels on several components of physical fitness, such as cardiovascular endurance, muscular strength and endurance, and speed (Haga, 2008b; Hands, 2008; Tsiotra, Nevill, Lane, \& Koutedakis, 2009).

Recent studies show a significant relationship between actual motor competence and perceived competence (LeGear et al., 2012; Robinson, 2010). Young children usually have positive perceptions of their physical competence, although their actual competence might be different and usually low. LeGear et al. (2012) said that these positive perceptions at preschool age provide "a window of opportunity" for fostering skillfulness.

Many children participate in organized sports to build physical and social skills (Patel, Soares, \& Wells, 2017; Washington et al., 2001). Playing sports depends on the child's physical growth and neurodevelopmental readiness (Patel et al., 2017). Therefore, working with children tends awareness of the child's level at different stages of development and needs specific strategies to optimize his abilities in each age group (Patel et al., 2017). Different types of PA can be very stimulating in the preschool-age by organizing various forms of play and socializing with other children, promoting learning, memory and motor patterns. Gallahue, Ozmun \& Goodway (2011) thinks that physical activity positively affects fundamental movement patterns and encourages learning the sports technique of performing some elements. Furthermore, attending institutions in early childhood such as kindergarten (Sabo, 2003, 2004; Venetsanou \& Kambas, 2010), recreational and sports clubs (Radošević, Gavrilović, Veselinović, \& Parčina, 2018; Temple, Crane, Brown, Williams, \& Bell, 2016), and family indoor and outdoor activities (Barnett, Hinkley, Okely, \& Salmon, 2013) have a positive impact on child motor learning and development. Temple et al. (2016) have found that the more active categories of physical activities, active recreation and organized sports predict at least one subtype of motor skill in preschool children. However, since the girls were associated only with stork balance, the same study indicates that light needs to be shed on optimally portraying young girls' motor skill proficiency and the relationships between their participation and motor skills (Temple et al., 2016). Also, Olesen, Kristensen, Ried-Larsen, Grøntved, \& Froberg (2014) emphasize the large variation of PA among preschool ages, indicating that girls, in particular, are susceptible to the environment offered for PA during the preschool period.

This study purpose was to determine differences in motor skills of preschool girls aged 5 to 7 from Serbia according to participation in organized physical activities divided into three groups: rhythmic gymnastics, sports school and control group. Specific tasks of this research were related to establishing the characteristics of each group according to the level of motor competence in manual dexterity, aiming and catching, balance and total test score. Furthermore, to determine which motor skill best discriminates between groups, homogeneity and distance between groups will be determined.

\section{Materials and methods}

\section{Study participants}

Ninety-one girls aged 5-7 years (mean \pm 6.4 ) were selected in the city of Niš, Republic of Serbia. The sample of participants was divided into three subsamples: Control group $(\mathrm{n}=41)$, rhythmic gymnastics $(\mathrm{n}=25)$ and sports school $(\mathrm{n}=25)$.

The control group were children from kindergarten who did not participate in sports activities except for those in PE of the kindergarten curriculum. Rhythmic gymnastics has a program basic of rhythmic gymnastics and learning group choreography without requisites. Girls were also introduced to the basic apparatus of a ball, hoop and rope. The sports school program has been designed with various activities for preschoolers to learn and improve fundamental motor skills properly. Since the data was collected in May, the criterion was to have attended at least $75 \%$ of classes since September. Classes were three times per week for 60 minutes. All programs are supervised by physical educators and coaches who have 30 years of experience working with children. It should be noted that there is an exact reason we can compare these different programs - fundamental movement skills are practised in all sports schools.

\section{Study organization}

Motor development was assessed using the Movement Assessment Battery for Children-2 (MABC-2 test) proposed by Henderson et al., 2007. The MABC-2 test assesses in the three motor domains: Manual Dexterity (MD), Aiming \& Catching (AC), and Balance (BAL) within eight test items that differ from age bands (ABs); 3-6 years old (AB1), 7-10 years old (AB2), and 11-16 years (AB3). AB1 for 5 to 6 years and AB2 for 7 years old are used for this study. The performance test, used in this study as a research tool, is also used in clinical settings to identify children with motor difficulties or "at-risk" of or have developmental coordination disorder.

Children were tested individually. The assessment required a quiet environment not to disturb participants during the testing. Manual dexterity tasks took place in the classroom while aiming \& catching and balance tasks were performed in the gym. All tasks were clearly explained and demonstrated. The child had two attempts for each task.

The study was approved by the Ethical Commission of Faculty of Physical Culture, Palacky University Olomouc, following the principles established by the Helsinki Declaration of the World Medical Association (WMA). Furthermore, principals, teachers and parents were informed about the research goal. In addition, all parents and guardians have signed a written form confirming participation. Data were collected during the internship in cooperation with the Faculty of Sport and Physical Education University of Niš, 
Table 1. Descriptive statistics contingency tables for motor proficiency between girls oriented to organized physical activity

\begin{tabular}{|c|c|c|c|c|c|c|c|c|c|}
\hline \multicolumn{2}{|c|}{ MABC-2 } & \multicolumn{2}{|c|}{ Below average } & \multicolumn{2}{|c|}{ Average } & \multicolumn{2}{|c|}{ Above average } & \multirow[b]{2}{*}{$\mathbf{p}$} & \multirow[b]{2}{*}{ c } \\
\hline & & $\mathbf{n}$ & $\%$ & $\mathbf{n}$ & $\%$ & $\mathbf{n}$ & $\%$ & & \\
\hline \multirow{3}{*}{$\mathrm{MD}$} & Control group & 9 & 22.0 & 12 & 29.3 & 20 & 48.8 & .742 & .145 \\
\hline & R.gymnastics & 5 & 20.0 & 8 & 32.0 & 12 & 48.0 & & \\
\hline & Sports school & 3 & 12.0 & 11 & 44.0 & 11 & 44.0 & & \\
\hline \multirow{3}{*}{$\mathrm{AC}$} & Control group & 25 & $61.0^{*}$ & 12 & 29.2 & 4 & 9.8 & .001 & .354 \\
\hline & R.gymnastics & 6 & 24.0 & 8 & 32.0 & 11 & $44.0^{\star}$ & & \\
\hline & Sports school & 10 & 40.0 & 9 & 36.0 & 6 & 24.0 & & \\
\hline \multirow{3}{*}{ BAL } & Control group & 14 & 34.1 & 11 & 26.9 & 16 & 39.0 & .273 & .231 \\
\hline & R.gymnastics & 5 & 20.0 & 6 & 24.0 & 14 & $56.0^{*}$ & & \\
\hline & Sports school & 6 & 24.0 & 11 & 44.0 & 8 & 32.0 & & \\
\hline \multirow{3}{*}{ TTS } & Control group & 13 & $31.7^{\star}$ & 16 & 39.0 & 12 & 29.3 & .042 & .313 \\
\hline & R.gymnastics & 1 & 4.0 & 9 & 36.0 & 15 & $60.0^{*}$ & & \\
\hline & Sports school & 4 & 16.0 & 10 & 40.0 & 11 & 44.0 & & \\
\hline
\end{tabular}

Note: MD - manual dexterity; AC - aiming and catching; BAL - balance; TTS - Total test score; Below Average score $\leq 37$ percentiles;

Average 50-75 percentiles, and Above average $\geq 84$ at MABC- 2 test, $c-$ Pearsons coefficient of contingency, p-probability $\chi 2$ test

Serbia. The examiners were PhD students, postgraduate in Adapted Physical Activity from Czech and Serbia.

\section{Statistical analysis}

First, for this study, different cut off points are made to categorize children according to results of MABC-2 test component scores: below-average (scores $\leq 37$ percentile), average (50 to 75 percentile), and above-average (scores $\geq$ 84 percentile). Second, descriptive statistics were analyzed to determine the basic characteristics of participants according to the level of motor competence, Pearson's $\chi^{2}$ test for continency tables and proportions between and within groups association. Therefore, Multivariate analysis of variance (MANOVA) and discriminant analysis was applied on scaled data. Univariate procedures follow up with the univariate Roy test and Post Hoc Bonferroni. The Pearson contingency coefficient (c) from 0 - 1 and eta square $(\eta 2)$ are estimated effect sizes $0.01,0.06,0.14$ as small, medium, large. In addition, a discriminant coefficient was calculated to identify potentially significant contributors among variables. An indicator of the similarity and difference between groups has been presented by Mahalanobis distance and Cluster tree. The statistical significance was set at $\mathrm{p}<0.05$. The data were analyzed in IBM SPSS Statistics for Windows, Version 21.0. and the statistical program of Smartline agency (Dolga, Novi Sad, Serbia).

\section{Results}

Table 1 shows the level of motor skills Manual Dexterity, Aiming \& Catching, Balance and Total Test Score in percentage (\%). In addition, descriptive statistics crosstabs show the level of motor proficiency for each group concerning their scores. Attention is being drawn to significant differences between and within groups based on proportions. The descriptive procedure can only suggest some individual motor skills characteristics, while the significant differences between groups related to motor proficiency will be analyzed further.

Manual dexterity. Most of the girls had excellent manual dexterity scores. Above the average range from 44\%-48.8\%, and average range from $29.3 \%$ to $44 \%$. Below average scored $12 \%-22 \%$ of participants. Association between groups related to fine motor skills has not been found $[\chi 2(4)=1.967$, $\mathrm{p}=0.742]$ Pearson's coefficient of contingency was very low $\mathrm{C}=0.145$.

Aiming and catching. In total, 29 girls score on average, ranging in groups from $29.3 \%-36 \%$. The majority of girls from the control group, $61 \%$ and $40 \%$ from the sports school group, score below average. Based on proportion, this frequency was statistically significant in the control group than the frequency of average $(n=12,29.3 \% \mathrm{p}=0.005)$ and above-average $(\mathrm{n}=4,9.8 \% \mathrm{p}=0.000)$. The Rhythmic gymnastics (44\%) were more likely to score above average than girls from the control group. There is an association between aiming and catching tasks and girls groups since the $\chi 2(4)=13.034, p=0.011$, Pearson's coefficient of contingency showed a low correlation $\mathrm{c}=0.354$.

Balance. There is not enough evidence to suggest an association between groups and balance $\chi 2(4)=5.142$, $p=0.273$, Pearson's coefficient of contingency $c=0.231$ correlation is low. However, $56 \%$ of the girls who attended rhythmic gymnastics reached an above-average score, and that frequency was significantly higher than average scores $(\mathrm{n}=6,24.0 \% \mathrm{p}=0.025)$ and below-average scores $(\mathrm{n}=5$, $20.0 \% \mathrm{p}=0.012$ ). They were slightly better than girls from the control group and sports school.

Total test score. Based on the final results, $31.7 \%$ of girls from the control group scored below average, significantly higher than the rhythmic group $(4.00 \% \mathrm{p}=0.016)$. Average scores range from $36 \%$ to $40 \%$. The $96 \%$ of rhythmic gymnastics scored above 50 percentile. Since only one girl scored below the norm, they were more likely to score $\geq 84$ percentile $\mathrm{p}=0.010 .84 \%$ of girls from sports school score 50 percentile and above, frequency above average was signif- 
icant $\mathrm{p}=0.036$ since four respondents scored on and below 37 percentile. Association has been found between groups and total test score since $\chi 2(4)=9.889, \mathrm{p}=0.042, \mathrm{c}=0.313$ correlation is low.

According to their participation in organized physical activity, the significant difference in motor competence of girls aged 5-7 years are presented in Tables 2 and 3.

Significant Manova $\mathrm{F}_{(8,170)}=2.719, \mathrm{p}=0.008$ and discriminant analysis $\mathrm{F}_{(8,170)}=2.686, \mathrm{p}=0.008$ means that there is a significant difference and a clearly defined boundary in motor competence between preschool girls according to their participation in organized physical activity. Follow up univariate test has found a significant difference in aiming \& catching $\mathrm{F}_{(2,88)}=7.277, \mathrm{p}<0.001, \eta^{2}=139$ and TTS $\mathrm{F}_{(2,88)}=5.394, \mathrm{p}=0.006, \eta^{2}=0.105$. Girls attending rhythmic gymnastics were significantly better in aiming \& catching $\mathrm{p}<0.001$, and the Total test score $\mathrm{p}=0.006$ than girls from the control group. The coefficient of discrimination indicates the most potent contribution to discrimination between groups in aiming and catching $(0.074)$, balance $(0.043)$, total test score (0.041).

Table 4 shows characteristics and homogeneity of girls from the control group, rhythmic gymnastics and sports school, related to $\mathrm{MD}, \mathrm{AC}, \mathrm{BAL}$, and TTS. According to participation in organized physical activity, preschool girls were significantly different in some domains of motor competence. Once again transferred to percentage, specific skills

Table 2. MANOVA and discriminant analysis significant differences in motor competence between preschool girls according to their participation in organized physical activity

\begin{tabular}{cccc}
\hline Analysis & $\mathbf{n}$ & $\mathbf{F}_{(8,170)}$ & $\mathbf{p}$ \\
\hline MANOVA & 4 & 2.719 & 0.008 \\
Discriminant & 4 & 2.686 & 0.008 \\
\hline
\end{tabular}

appeared to be the best discriminators, aiming and catching with $41.4 \%$, balance skills with $24 \%$, and total test score with $22.9 \%$.

Table 5 shows the distance between the control group, rhythmic gymnastics, and sports to motor proficiency.

By calculating the Mahalanobis distance between the groups, another indicator of similarities or differences was

Table 5. Distance (Mahalanobis) between the control group, rhythmic gymnastics, and sports school to motor proficiency

\begin{tabular}{lccc}
\hline \multicolumn{1}{c}{ Indicators } & $\begin{array}{c}\text { Control } \\
\text { group }\end{array}$ & $\begin{array}{c}\text { Rhythmic } \\
\text { gymnastics }\end{array}$ & $\begin{array}{c}\text { Sports } \\
\text { school }\end{array}$ \\
\hline Control group & 0.00 & 1.05 & 0.78 \\
Rhythmic gymnastics & 1.05 & 0.00 & 0.73 \\
Sports school & 0.78 & 0.73 & 0.00 \\
\hline
\end{tabular}

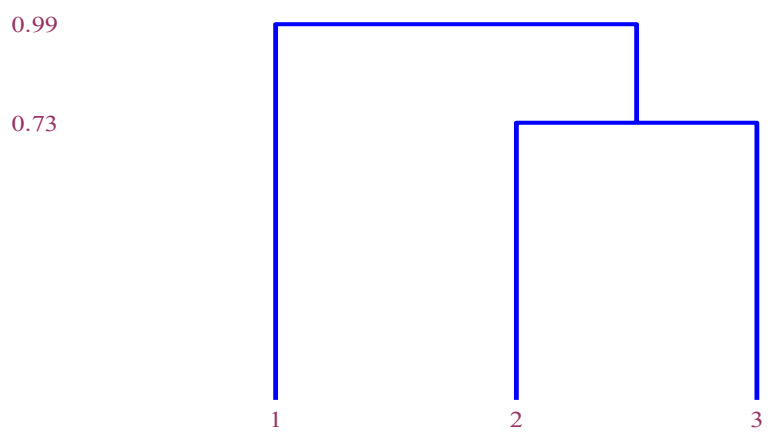

Fig. 1. Control group (1), Rhythmic gymnastics (2), Sports school (3)

obtained - distances of different spaces $\left(\mathrm{D}^{2}\right)$ can be compared. For example, the distances from Table 5 indicate that the slightest differences are between girls from sports school

Table 3. Univariate Roy test significant differences between groups related to manual dexterity, aiming and catching, balance, and total test score

\begin{tabular}{ccccc}
\hline Indicators & $\mathbf{F}_{(2,88)}$ & $\mathbf{p}$ & $\boldsymbol{\eta}^{2}$ & c. disc. \\
\hline MD & 0.983 & 0.378 & 0.001 & 0.021 \\
AC & 7.277 & 0.001 & 0.139 & 0.074 \\
BAL & 1.739 & 0.182 & 0.027 & 0.043 \\
TTS & 5.394 & 0.006 & 0.105 & 0.041
\end{tabular}

Note: MD - manual dexterity; AC - aiming and catching; BAL - balance; TTS - total test score; $\eta^{2}$ - effect size coefficient; c. disc - discriminative coefficient

Table 4. Characteristics and homogeneity of girls from the control group, rhythmic gymnastics, and sports school related to manual dexterity, aiming and catching, balance, and total test score

\begin{tabular}{ccccc}
\hline Indicators & Control group & Rhythmic gymnastics & Sports school & Contribution \% \\
\hline AC & lower ${ }^{*}$ & higher $^{*}$ & - & 41.4 \\
BAL & - & higher & - & 24.0 \\
TTS & lower ${ }^{*}$ & higher & - & 22.9 \\
MD & - & - & - & 11.7 \\
n/m & $26 / 41$ & $18 / 25$ & $14 / 25$ & \\
$\%$ & 63.4 & 72.0 & 56.0 & \\
\hline
\end{tabular}


and rhythmic gymnastics $\mathrm{D}^{2}=0.73$ (moderate). The more significant differences are between rhythmic gymnastics and control group $\mathrm{D}^{2}=1.05$ (greatest distance).

\section{Discussion}

The purpose of this study was to determine differences in motor skills of preschool girls according to participation in organized physical activities. Specific tasks of this research were related to establishing the characteristics of each group according to the level of motor competence and determining which motor skill the best discriminate between groups.

Multivariate ANOVA and discriminative analysis were significant at $p=0.008$. Significant differences have been found in girls attending rhythmic gymnastics in aiming \& catching on the upper bound of moderate effect size $\left(\eta^{2}=139\right)$, and total test score moderate effect size $\left(\eta^{2}=0.105\right)$ compared to girls who did not participate in organized physical activity.

Based on Table 4, it can be concluded that the control group's homogeneity is $63.4 \%$ (higher), which means that 15 of 41 girls have other characteristics than the characteristics of their group. However, girls from the control group mainly had achieved scores significantly lower in aiming \& catching and total test score. Moreover, $61 \%$ expressed lower than average aiming and catching skills. The homogeneity of the rhythmic gymnastics group was higher $(72.0 \%)$. Seven girls of 25 had other characteristics. They had achieved scores significantly higher aiming \& catching and total test score. In addition, a higher amount of the girls who practised rhythmic gymnastics scored above 50 percentile on balance (80\%). Characteristics of sports schools have 14 out of 25 girls. Homogeneity was $56.0 \%$ (smaller). They mostly had resulted from the average and above average. The total test score norm of $\geq 50$ percentile meet $68.3 \%$ girls in the control group, $84 \%$ in the sports school group, and $96 \%$ in rhythmic gymnastics.

Based on the presented dendrogram in Figure 1, it can be noticed that the closest are rhythmic gymnastics and sports school with a distance of 0.73 , and the most significant difference is between the control group and rhythmic gymnastics, with a distance of 0.99 .

Our results confirm our expectations and previous findings that children involved in structured and organized physical activity have better-developed motor competence, gross motor skills and manipulative skills (Djordjević, Valková, Nurkić, Djordjević, \& Dolga, 2021; Hardy, O’Hara, Rogers, St George, \& Bauman, 2014; Krombholz, 2006; Šalaj, Krmpotić, \& Stamenković, 2016). Moreover, children who consistently engage in sports from 6-7 years of age during the following years showed better levels of coordination than children who only partially participated or did not participate in the sports-recreational environment (Vandorpe et al., 2012). Our results align with Ribeiro-Silva (2016) study, where girls who practised rhythmic gymnastics had higher scores in the object control subtest and motor quotient than girls who practised swimming. Furthermore, this difference in the performance of object control skills in girls impacted the motor quotient measure (Ribeiro-Silva, 2016). Those findings were similar to our results, as specific skills appeared to be the best discriminators, aiming and catching with $41.4 \%$, balance skills with $24 \%$, and total test score $22.9 \%$.
Apart from regular training, the probable reason why girls from rhythmic gymnastics have improved scores in aiming and catching is the perception of this aesthetic-coordinative sport. Practising rhythmic gymnastics in girls encourage the need to learn new skills with apparatus, such as throwing a ball in the air and catching, manipulating a hoop and a ribbon, skipping a rope in free time. Šalaj et al. (2019) found significant differences in gross motor quotient and locomotor skills in the selected girls compared to the non-selected girls from artistic gymnastics. However, results from this study suggest that the female competition program in preschool-age favourites the development of locomotor but not manipulative motor skills, and they propose a multilateral exercise program (Šalaj et al., 2019). This conclusion can be applied to our girls from sports school, although $84 \%$ had good results on the total test score, $40 \%$ of girls had aiming and catching skills below average.

The control group of girls, as could be assumed, had the statistical significance of the differences because that group did not have additional physical activities to improve the overall result. Different studies have shown that preschool children spend their school time in three different contexts: traditional classes, physical education (PE), and free schoolyard play (Flôres, Rodrigues, Copetti, Lopes, \& Cordovil, 2019). Physical education classes or schoolyards play at preschool are the only environmental opportunity to play sports, games, gymnastics, and dance for many children. However, since motor competence does not develop naturally (Drenowatz, 2021); instead, it requires instruction and purposeful practice, feedback, in addition to free play (Logan et al., 2019). Our research indicates preschool PE should propose more physical activity in girls and skill practice time, especially on-task regarding object control or ball skills. As Drenowatz (2021) stated, children may not be exposed to movements that promote the development of manipulative skills during daily activities, and facility control skills may not be as integrated with daily PAs as locomotor skills and stability skills.

Exercise is an essential condition for the creation of motor habits. Therefore, starting with children on some sports activities is recommended, of course, very carefully chosen for young children (Parízková, 2016). When proper motor habits and skills are introduced on time, a sound basis for later performance and interest in exercise is created.

\section{Conclusion}

To improve balance and fine and gross motor coordination during early childhood is challenging, and to make progress, children at that young age can only do it through the tasks and vigorous play that sports schools can provide (Djordjević et al., 2021). In this study, the coefficient of discrimination found the most significant contribution to differences between girls in aiming and catching, balance and total test score. Furthermore, girls from rhythmic gymnastics significantly differ from control group girls in aiming \& catching and total test score with a moderate effect size. According to the level of motor competence, $61 \%$ from the control group and $40 \%$ from the sports school group scored below average on aiming \& catching. The total test score of $\geq 50$ percentile achieved $68.3 \%$ of girls in the control group, $84 \%$ in the sports school group, and $96 \%$ in rhythmic gymnastics. 
Our results confirm that sports practice contributes to the development of motor capabilities and influences individual differences in children's scores. Additionally, as Berk (2008), we notice that the children's sports school program improves and upgrades previously acquired motor experiences. Further, our findings can contribute to understanding how important it is to promote object control skills games for girls and older preschoolers generally. The implications are addressed for parents, physical education teachers, early childhood educators and early childhood and physical activity policymakers and recommend structured physical activity experiences that promote motor competence in preschoolers.

\section{Acknowledgement}

This study was part of the project "Assessment of motor development in 5-7-year-old children involved in organized physical activities" (Code No. IGA_FTK_2014018).

\section{Conflict of interest}

The authors declare no conflict of interest.

\section{References}

Sugden, D., \& Wade, M. (2013). Typical and atypical motor development. Clinics in Developmental Medicine, UK: Mac Keith Press.

Newell, K. M. (1986). Constraints on the Development of Coordination. Motor Development in Children: Aspects of Coordination and Control, pp. 341-360. https://doi.org/10.1007/978-94-009-4460-2_19

Giagazoglou, P., Kabitsis, N., Kokaridas, D., Zaragas, C., Katartzi, E., \& Kabitsis, C. (2011). The movement assessment battery in Greek preschoolers: The impact of age, gender, birth order, and physical activity on motor outcome. Research in Developmental Disabilities, 32(6), 2577-2582. https://doi.org/10.1016/j.ridd.2011.06.020

Venetsanou, F. \& Kambas, A. (2010). Environmental factors affecting preschoolers motor development. Early Childhood Educational Journal, 37, 319-327.

Gallahue, D. L. \& Ozmun, J.C. (2006). Understanding Motor Development: Infants, Children, Adolescents, Adults (6th ed.). Dubuque, IA: McGraw-Hill.

MacNamara, A., Collins, D., Bailey, R., Toms, M., Ford, P. and Pearce, G. (2011). Promoting Lifelong Physical Activity and High Level Performance: Realizing an Achievable Aim for Physical Education. Physical Education \& Sport Pedagogy, 16(3), 265-278.

Henderson, S.E., Sugden, D.A., \& Barnett, A. (2007). Movement Assessment Battery for Children-2 examiner's manual. London, England: Harcourt Assessment.

Hardy, L. L., King, L., Farrell, L., Macniven, R., \& Howlett, S. (2010). Fundamental movement skills among Australian preschool children. Journal of Science and Medicine in Sport, 13(5), 503-508. https://doi.org/10.1016/j.jsams.2009.05.010

Stodden, D. F., Langendorfer, S. J., Goodway, J. D., Roberton, M. A., Rudisill, M. E., Garcia, C., \& Garcia, L. E. (2008). A developmental perspective on the role of motor skill competence in physical activity: An emergent relationship. Quest, 60(2), 290-306.

https://doi.org/10.1080/00336297.2008.10483582

Wrotniak, B. H., Epstein, L. H., Dorn, J. M., Jones, K. E., \& Kondilis, V. A. (2006). The relationship between motor proficiency and physical activity in children. Pediatrics, 118(6), e1758-1765. https://doi.org/10.1542/peds.2006-0742

Barnett, L. M., Morgan, P. J., van Beurden, E., \& Beard, J. R. (2008). Perceived sports competence mediates the relationship between childhood motor skill proficiency and adolescent physical activity and fitness: a longitudinal assessment. International Journal of Behavioral Nutrition and Physical Activity, 5, 40.

https://doi.org/1479-5868-5-40

Hands, B. (2008). Changes in motor skill and fitness measures among children with high and low motor competence: A five-year longitudinal study. Journal of Science and Medicine in Sport, 11(2), 155-162.

Ivashchenko, O., Nosko, Y., Bartik, P., \& Makanin, O. (2020). Gender-related peculiarities of 7-year-old schoolchildren's motor fitness. Teoria ta Metodika Fizicnogo Vihovanna, 20(4), 228-233. https://doi.org/10.17309/tmfv.2020.4.05

Haga, M. (2008a). The relationship between physical fitness and motor competence in children. Child: Care, Health and Development, 34(3), 329-334.

Vedul-Kjelsås, V., Sigmundsson, H., Stensdotter, A. K., \& Haga, M. (2012). The relationship between motor competence, physical fitness and self-perception in children. Child: Care, Health and Development, 38(3), 394-402.

Haga, M. (2008b). Physical fitness in children with movement difficulties. Physiotherapy, 94(3), 253-259.

Tsiotra, G. D., Nevill, A. M., Lane, A. M., \& Koutedakis, Y. (2009). Physical Fitness and Developmental Coordination Disorder in Greek Children. Pediatric Exercise Science, 21(2), 186-195.

LeGear, M., Greyling, L., Sloan, E., Bell, R. I., Williams, B. L., Naylor, P. J., \& Temple, V. A. (2012). A window of opportunity? Motor skills and perceptions of competence of children in kindergarten. International Journal of Behavioral Nutrition and Physical Activity, 9, 29. https://doi.org/10.1186/1479-5868-9-29

Robinson, L. E. (2010). The relationship between perceived physical competence and fundamental motor skills in preschool children. Child: Care, Health and Development, 37(4),589-96.

https://doi.org/10.1111/j.1365-2214.2010.01187.x

Patel, D., Soares, N., \& Wells, K. (2017). Neurodevelopmental readiness of children for participation in sports. Translational Pediatrics, 6(3), 167-173. https://doi.org/10.21037/tp.2017.05.03

Gallahue, D. L. \& Ozmun, J.C. \& Goodway, J.D. (2011). Understanding Motor Development: Infants, Children, Adolescents, Adults. (7th ed.). Boston, MA: McGraw-Hill.

Sabo, E. (2003). Structure of motoric space and differences in motoric abilities of the preschool boys at the enrolment in elementary school. Fizička kultura, Beograd, 56(1-4), 10-17.

Sabo, E. (2004). Impact of time spent in nursery school towards boy's maturity for entering primary school. Pedagoška stvarnost, 50(3-4), 301-310. 
Radošević, I., Gavrilović, A., Veselinović, J., \& Parčina, I. (2018). Preschool sport management: the role of basic sports in preschools. Facta Universitatis, 16(2), 487-492. https://doi.org/10.1007/978-94-009-4460-2_19

Temple, V. A., Crane, J. R., Brown, A., Williams, B. L., \& Bell, R. I. (2016). Recreational activities and motor skills of children in kindergarten. Physical Education and Sport Pedagogy, 21(3), 268-280.

https://doi.org/10.1080/17408989.2014.924494

Barnett, L., Hinkley, T., Okely, A. D., \& Salmon, J. (2013). Child, family and environmental correlates of children's motor skill proficiency. Journal of Science and Medicine in Sport, 16(4), 332-336.

https://doi.org/10.1016/j.jsams.2012.08.011

Olesen, L. G., Kristensen, P. L., Ried-Larsen, M., Grøntved, A., \& Froberg, K. (2014). Physical activity and motor skills in children attending 43 preschools: A cross-sectional study. BMC Pediatrics, 14(1), 1. https://doi.org/10.1186/1471-2431-14-229

Djordjević, I., Valková, H., Nurkić, F., Djordjević, S., \& Dolga, M. (2021). Motor proficiency of preschool boys related to organized physical activity. Journal of Physical Education and Sport, 21(3), 2258-2265.

https://doi.org/10.7752/jpes.2021.s3287

Hardy, L. L., O'Hara, B. J., Rogers, K., St George, A., \& Bauman, A. (2014). Contribution of organized and nonorganized activity to children's motor skills and fitness. Journal of School Health, 84(11), 690-696. https://doi.org/10.1111/josh.12202

Krombholz, H. (2006). Physical performance in relation to age, sex, birth order, social class, and sports activities of preschool children. Perceptual and Motor Skills, 102(2), 477-484. https://doi.org/10.2466/PMS.102.2.477-484

Šalaj, S., Krmpotić, M., \& Stamenković, I. (2016). Are Specific Programs a Threat To Overall Motor Development of Preschool Children? Kinesiologia Slovenica, 22(1), 47-55.
Vandorpe, B., Vandendriessche, J., Vaeyens, R., Pion, J., Matthys, S., Lefevre, J., ... Lenoir, M. (2012). Relationship between sports participation and the level of motor coordination in childhood: A longitudinal approach. Journal of Science and Medicine in Sport, 15(3), 220-225. https://doi.org/10.1016/j.jsams.2011.09.006

Ribeiro-Silva, P. C. (2016). Influence of the context of oriented sports practice on the global motor development of children. [Master's thesis, Federal University of Minas Gerais]. https://repositorio.ufmg.br/bitstream/1843/BUOSAQWFVM/1/disserta_o_ribeiro_silva_2016.pdf

Šalaj, S., Milčić, L., \& Šimunović, I. (2019). Differences in motor skills of selected and non-selected group of children in artistic gymnastics in the context of their motor development. Kinesiology, 51(1), 133-140. https://doi.org/10.26582/k.51.1.16

Flôres, F. S., Rodrigues, L. P., Copetti, F., Lopes, F., \& Cordovil, R. (2019). Affordances for Motor Skill Development in Home, School, and Sport Environments: A Narrative Review. Perceptual and Motor Skills, 126(3), 366-388. https://doi.org/10.1177/0031512519829271

Drenowatz, C. (2021). Association of motor competence and physical activity in children - does the environment matter? Journal of Physical Education and Sport, 21(1), 514-519. https://doi.org/10.7752/jpes.2021.s1055

Logan, K., Cuff, S., LaBella, C. R., Brooks, M. A., Canty, G., Diamond, A. B., ... Emanuel, A. (2019). Organized sports for children, preadolescents, and adolescents. Pediatrics, 143(6). https://doi.org/10.1542/peds.2019-0997

Parízková, J. (2016). Nutrition, physical activity, and health in early life (2nd ed.). Bocan Rotan, Fla: CRC Press.

\title{
ВІДМІННОСТІ У РУХОВІЙ ПІДГОТОВЦІ ДІВЧАТ ДОШКІЛЬНОГО ВІКУ, ПОВ'ЯЗАНІ 3 ОРГАНІЗОВАНОЮ ФІЗИЧНОЮ АКТИВНІСТЮ
}

\author{
Івана Джорджевич ${ }^{1 A B C D E}$, Хана Валкова ${ }^{2 A B D E}$, Емілія Петковіч ${ }^{3 \mathrm{ABCD}}$ \\ 'Університет Палацького \\ ${ }^{2}$ Університет Масарика \\ ${ }^{3}$ Ниський університет
}

Авторський вклад: А - дизайн дослідження; В - збір даних; C - статаналіз; D - підготовка рукопису; Е - збір коштів

Реферат. Стаття: 7 с., 4 табл., 1 рис., 38 джерел.

Мета дослідження - визначити рівень рухової компетентності та відмінності у моторних навичках дівчат дошкільного віку від 5 до 7 років із Сербії залежно від участі в організованій фізичній активності.

Матеріали та методи. 91 дівчинку 5-7 років (середне значення $\pm 6,4$ ) було розділено на три підвибірки: контрольну групу, групу художньої гімнастики та групу спортивної школи. Дівчаток оцінювали за допомогою тесту
МАВС-2. Використовуючи описову статистику, проаналізовано основні характеристики учасниць за рівнем рухової компетентності. Крім того, були застосовані критерій $\chi^{2}$ Пірсона для факторних таблиць, MANOVA та дискримінантний аналіз, щоб знайти відмінності у руховій підготовці груп.

Результати. У дівчат, які відвідують художню гімнастику, були виявлені значні відмінності у прицілюванні та 
ловлі на верхній межі помірної величини ефекту ( $\mathrm{p}<0,001$, $\left.\eta^{2}=139\right)$ та помірна величина ефекту у загальному результаті тесту ( $\left.\mathrm{p}=0,006, \eta^{2}=0,105\right)$ порівняно з дівчатами, які не брали участі в організованій фізичній активності. Коефіцієнт дискримінації пояснив відмінності у дівчат у прицілюванні та ловлі із внеском 41,4\%, у навичках рівноваги - 24\%, та загальному результаті тесту - 22,9\%. За рівнем рухової компетентності $61 \%$ з контрольної групи та $40 \% 3$ групи спортивної школи набрали нижчу середню оцінку 3 прицілювання та ловлі. Загальний бал тесту $\geq 50$ процентилів досягли $68,3 \%$ дівчат у контрольній групі, $84 \%$ у групі спортивної школи та 96\% у групі художньої гімнастики.
Висновок. Дане дослідження підтверджує, що заняття спортом сприяють розвитку рухових здібностей та впливають на індивідуальні відмінності у результатах дітей. Результати дослідження допомагають зрозуміти важливість популяризації ігор для розвитку навичок керування предметом серед дівчаток та дітей старшого дошкільного віку загалом.

Ключові слова: рухова компетентність, дошкільний навчальний заклад, дівчата, організована фізична активність, МАВС-2.

\section{Information about the authors:}

Djordjevic I.: hacienda018@hotmail.com; https://orcid.org/0000-0002-3497-6242; Department of Adapted Physical Activity, Faculty of Physical Culture, Palacky University Olomouc, tr. Miru, 117, Olomouc, 771 47, Czech Republic.

Valkova H.: valkova@fsps.muni.cz; https://orcid.org/0000-0002-2972-1210; Department of Social Sciences and Sport Management, Faculty of Sport Studies, Masaryk University, Kamenice, 753/5, Brno, Czech Republic.

Petkovic E.: petkovicemilija@yahoo.com; https://orcid.org/0000-0002-0031-0338; Faculty of Sport and Physical Education, University of Niš, Čarnojevića, 10A, 18000, Niš, Serbia.

Cite this article as: Djordjević, I., Valkova, H., \& Petkovic, E. (2021). Differences of Motor Proficiency in Preschool Girls Related to Organized Physical Activity. Teoriâ ta Metodika Fizičnogo Vihovannâ, 21(4), 357-364. https://doi.org/10.17309/tmfv.2021.4.11

Received: 10.11.2021. Accepted: 24.11.2021. Published: 25.12.2021

This work is licensed under a Creative Commons Attribution 4.0 International License (http://creativecommons.org/licenses/by/4.0). 